\title{
Lenfödem Tanı ve Tedavisine Güncel Bakış
}

\author{
Işıl Fazilet Turna®
}

Acıbadem Atakent Hastanesi, Fiziksel Tıp ve Rehabilitasyon, İstanbul, Türkiye

Işıl Fazilet Turna, Uzm. Dr.
İletişim:

Uzm. Dr. Işı Fazilet Turna

Acıbadem Atakent Hastanesi, Fiziksel Tıp ve Rehabilitasyon, İstanbul, Türkiye

Tel: +905302898782

E-Posta:sil.turna@acibadem.com
Gönderilme Tarihi : 15 Ağustos 2018

Revizyon Tarihi : 09 Ekim 2018

Kabul Tarihi : 10 Ekim 2018

\section{ÖZET}

Lenfödem, cilt ve cilt altı dokuda proteinden zengin interstisyel sıvının birikmesi ile oluşan kompleks bir durumdur. Ekstremitedeki hacimsel ve cilt dokusundaki kozmetik değişiklikler hastanın günlük yaşamını ve psikososyal durumunu olumsuz etkilemektedir ve tedavi edilmez ise ilerlemeye devam etmektedir. Lenfödem, primer ya da sekonder nedenlere bağlı olabilir. Primer lenfödemde en sık görülen anomali tipi, hipoplazik tip lenf damarlarıdır. Sekonder lenfödemin en sık tipi, gelişmiş ülkelerde meme kanseri cerrahisi sonrası görülürken gelişmekte olan ülkelerde, parazitlerdir (filaryazis). Lenfödemin tanısı, evrelendirilmesi ve şiddetinin ölçülmesinde henüz altın standart bulunmamaktadır. Öykü ve muayeneden sonra, klinik pratikte en sık kullanılan teknik ultrasonografidir. Lenfödem tedavisinin ilk basamağı ekstremiteyi normal ya da normale yakın boyuta ulaştırmak ve komplikasyonları önlemektir, çünkü tedavide kür yoktur. Komplet dekonjestif terapi, lenfödem ve ilişkili durumlarda kullanılan, manuel lenf drenajı, kompresyon tedavisi, remedeal egzersizler, cilt bakımından oluşan 4 bileşenli bir tedavidir. Bu tedavi 2 fazlı olarak yapılmaktadır. Faz 1 yoğun veya dekonjestif tedavidir. Faz 2 de ise bası giysileri ve gece bandajı ile faz 1 deki kazanımları sürdürebilmesi amaçlanır. Bu dönem ömür boyu devam eder. Sonuç olarak lenfödem, izole bir tablo veya hayatı tehdit eden sistemik bir sendrom olabilir. Tanı, tedavi ve takip aşamasında multidisipliner yaklaşıımalıdır.

Anahtar sözcükler: Lenfödem, Manuel lenf drenajı, Lenfatik sistem

\section{CURRENT OVERVIEW OF THE DIAGNOSIS AND TREATMENT OF LYMPHOEDEMA}

\section{ABSTRACT}

Lymphoedema is a complex condition caused by the collection of protein-rich interstitial fluid in the cutaneous and subcutaneous tissue. Cosmetic changes in cutaneous tissue and the volumetric changes of the extremity affect the daily life and psychosocial state of the patient negatively and continue to progress if not treated. Lymphedema may be the result of primary or secondary causes. The most common type of anomaly in the primary lymphedema is the hypoplasic lymphatic vessel type. The most common type of secondary lymphoedema is parasites (filariasis) in developing countries, while in the developed countries lymphoedema is mostly seen after breast cancer surgery. There is no gold standard yet for the diagnosis, staging, and severity of lymphoedema. After taking the patient's' history and physical examination, technical ultrasonography is often used firstly in clinical practice. The first step in the treatment of lymphoedema is to bring the extremity close to normal size and prevent complications hence there is no cure in the treatment. Complete decongestive therapy is a 4-component therapy consisting of manual lymph drainage, compression therapy, remedial exercises, and skin care, and is used in lymphatic and related conditions. This treatment has 2 phases. Phase 1 is intense or decongestive treatment. In Phase 2, it is aimed to sustain the gains of phase one with pressure garments and night bandages. This period lasts for life. As a result, lymphedema can be an isolated picture or a systemic syndrome that is life-threatening. A multidisciplinary approach should be performed during diagnosis, treatment, and follow-up.

Keywords: lymphoedema, manual lymph drainage, lymphatic system 
$\mathbf{T}$ ıp tarihine bakıldığında lenfatik sistem göreceli olarak geç keşfedilmiştir. Hipokrat beyaz kan içeren damar olarak tanımlamış, Aristoteles renksiz sıvı olarak bahsetmiştir. Rouviere 1932'de insan lenfatik sistemi hakkında bir kitap yayınlamıştır. Yeni teknolojik görüntüleme teknikleri ise lenfatik sistem hakkında farklı bir bakış açısı kazandırmıştır. M. Földi, A. Gregl, E. Kuhnke, S. Kubik ve J. Casley-Smith gibi araştırmacılar lenfoloji alanında önemli araştırmalar için önemli bir yol açmıştır (1).

Lenfödem, lenfatik sistemin transport kapasitesinin normal lenfatik yükün altına düştüğünde, cilt ve cilt altı dokuda proteinden zengin interstisyel sıvının birikmesi ile oluşan kompleks bir durumdur $(2,3)$. Lenfödem, izole bir tablo veya hayatı tehdit eden sistemik bir sendrom olabilir (2).

Dünyada yaklaşık 140-250 milyon, Amerika'da 2-3 milyon lenfödem hastası olduğu tahmin edilmektedir. Fakat tanı almamış, tedavisi gecikmiş veya tedaviye hiç ulaşmamış hastaların varlığı düşünüldüğünde, tahminlerin prevelansın altında olduğu düşünülmektedir (3-5).

Lenfödem, primer ya da sekonder nedenlere bağlı olabilir. Gelişmiş ülkelerde en sık meme kanseri cerrahisi sonrası görülürken gelişmekte olan ülkelerde, parazitler (filaryazis) lenfödemin en sık nedenidir $(3,5)$.

Ekstremitedeki hacimsel ve cilt dokusundaki kozmetik değişikliler hastanın günlük yaşamını ve psikososyal durumunu olumsuz etkilemektedir ve tedavi edilmez ise ilerlemeye devam etmektedir (6).

\section{Anatomi}

Lenfatik dolaşım, kardiyovasküler sisteme eşlik eden, vücuttaki iki vasküler sistemden biridir. Epidermis, kıl, tırnak, kıkırdak, kornea gibi avasküler yapılar, kemik iliği, merkezi sinir sistemi, orbita, pankreas adacıkları ve iç kulak hariç tüm vücudu bir ağ gibi sarar (6) (Şekil1).

Kan kapillerlerinden interstisyuma geçmiş sıvı ve içinde çözünmüş moleküllerin venöz sisteme geri taşınması, bağırsak tarafından emilmiş yağların kilus olarak taşınarak venöz sisteme aktarılması ve bağışıklık sisteminin düzenlenmesi lenfatik sistemin ana fonksiyonlarıdır $(4,7)$.

Lenf damarları, yerleşim yerine göre, yüzeyel (subkütanöz) damarlar ve derin (subfasial) damarlar olarak 2 ye ayrılır. Lenfatik drenajın çoğu cilt ve cilt altı dokuda olur. İki sistem perforan damarlar ile birbiriyle anastomoz

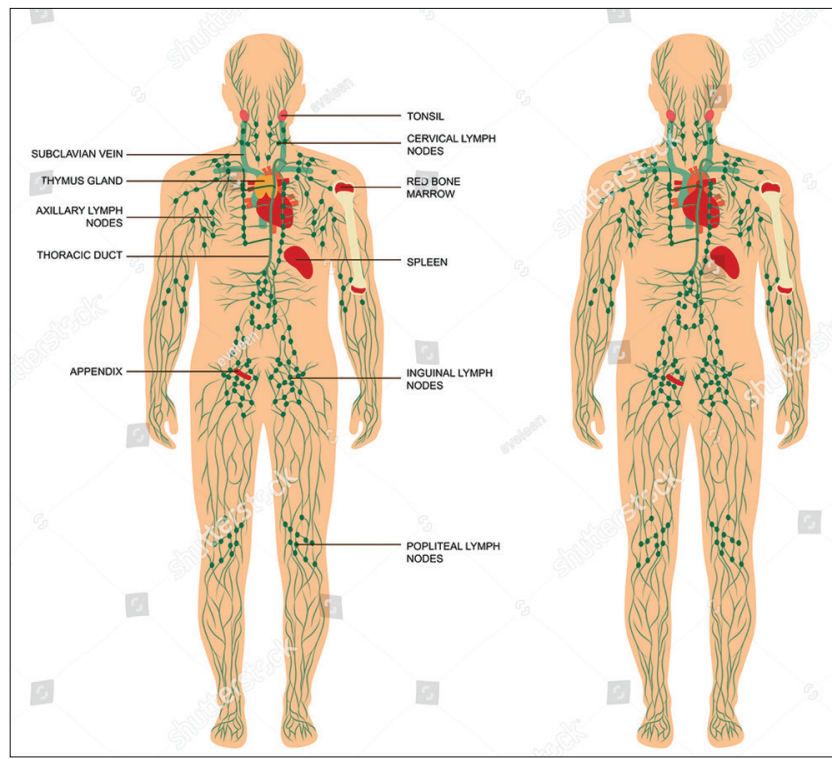

Şekil 1. Lenfatik Sistem

yapar (8). Lenf sıvısı, intestinal lenf damarlarındaki şilöz sıvı haricinde açık renkli ve yarı sıvı haldedir (9). İçeriğinde; proteinler, su, eritrosit, lökositler, lenfositler gibi hücreler, artık ürünler, bakteriler, antijen ve kanser hücreleri bulunur (8).

Lenf damarları, büyüklük sırasına göre ise lenf kapillerleri, prekollektörler, kollektörler, trunkuslar ve duktuslar olarak adlandırıırlar (10).

Kollektörlerin, proksimal ve distal kapakçığı arasındaki segmente lenfanjion denir. Lenfanjionlar, dinlenme sırasında, dakikada 10-12 otonomik kasılma yapar. Buna lenfanjiomotorisite denir (7). Lenfanjiomotorisiteyi etkileyen faktörler şunlardır; lenf sıvısındaki artış, lenfanjion duvarındaki eksternal gerilme (manuel lenf drenajı, bandajlama), ısı, iskelet kaslarının pasif ve aktif kasılmaları (lenf akımını 10-30 kez arttırabilir) (11), arteryel pulsasyon, diafragmatik solunum, santral vendeki negatif basınç, belirli doku hormonları (7). Lenfatikler ödeme karşı güvenlik faktörü olarak etki gösterirler. Dokularda sıvı birikmeye başlayınca lenf akımı 10 ile 50 kat artabilir (6).

Kollektörler, watershedler ile birbirinden ayrılan tributör veya drenaj alanları olarak adlandırılan vücut alanlarından lenf sıvısını bölgesel lenf nodlarına ordan da trunkuslara aktarırılar (9).

Trunkuslar en geniş lenf damarlarıdır ve derin yerleşirler. Organlardan, ekstremitelerden ve ilgili kadranlardan lenfi toplar ve iki büyük duktus olarak venöz açıya taşırlar (9). 
Duktuslar ise duktus torasikus ve sağ lenfatik duktustur. Duktus torasikus, umblikus seviyesindeki, lomber ve intestinal trunkuslardan gelen lenfi içeren, sisterna şiliden başlar. Asendan aorta yanında ilerleyerek, diaframı deler ve toraksta ilerler. Lenfatik sıvının, yaklaşık 3/4'ünü, sol internal juguler ven ve sol subklavian venin birleşme yeri olarak tanımlanan sol venöz açıya drene eder. Sağ lenfatik duktus, lenfin kalan 1/3'ünü sağ venöz açıya drene eder (8) (Şekil 1).

Lenf nodları, lenfatik damarların istasyonu olarak bilinir. Lenfatik sistemde yaklaşık olarak 600-700 civarında lenf nodu vardır (9). Nodların çoğu stratejik olarak patojenlerin giriş yeri olan bağırsaklarda ve baş-boyun bölgelerinde bulunur. Lokasyonlarına göre rejyonel ve interval lenf nodları olarak 2'ye ayrılır (10). Rejyonel lenf nodları, farklı deri veya organların drene olduğu lenf nodlarıdır. Kanser cerrahisinde lenf nodu diseksiyonunun hedefidir. İnterval lenf nodları ekstremitelerde bulunurlar. Lenf damarları, rejyonel lenf nodlarına giderken buradan geçerler (10). Lenf nodlarında, lenf içindeki protein konsantre edilir, bakteri, toksin, yabancı cisim ve kanser hücrelerinin filtresi sağlanır ve fazla sıvı kan kapillerlerine geçer. Günde yaklaşık 4-8 litre lenf sıvısı lenf nodlarında konsantre olmaktadır.

Şelaleler (watersheds), deri üzerinde drenaj bölgelerini birbirinden ayıran sınırları oluşturur (9). Sagittal (vertikal), yüzeysel lenfatik sistemi sağ ve sol olmak üzere 2 ye ayırır. Transvers (horizontal) yüzeysel lenfatik sistemi üst ve alt yarıya ayırır. Sagital ve horizontal watershedler gövdede 4 teritori (kadran) oluşturur (9).

Interteritoryal anastomozlar, vücudun lenf stazına karşı koruma mekanizmasıdır. Bir drenaj bölgesindeki lenf akışı kesintiye uğrarsa, anastomozların aktivasyonu ile drene edilebilir. Aksillo-aksiller anastomoz, inguino-inguinal anastomoz, aksillo-inguinal anastomozlar olarak adlandırilır. $(9,10)$.

\section{Lenfatik sistem yetmezliği}

Lenfatik sistem yetmezliği, lenfatik sistemdeki transport kapasitesinin lenfatik yükten fazla gelmesi sonucu oluşur. Dinamik, mekanik ve kombine yetmezlik olarak 3'e ayrılır $(7,12)$.

Dinamik yetmezlik, sağlam lenfatik yolların lenfatik yükünün artmasıdır. Artmış kollektör içi basınç damar duvarına hasar verir. Bu açıdan sekonder lenfatik hasarlanmayı önlemek için su yükünü azaltmak gerekir. Dinamik yetmezlikte manuel lenf drenajı ve bandajlama tedavisi yapılmamalıdır. Örneğin kalp yetmezliğindeki ödemde manuel lenf drenajı ve bandajlama kalbe dönen yükü arttıracağı için kesinlikle yapılmamalıdır $(7,12)$.

Mekanik yetmezlikte, lenfatik sistemin transport kapasitesinde azalma vardır. Cerrahi, radyasyon, travma ya da inflamasyon mekanik yetmezliğe yol açabilir.

Kombine yetmezlikte, transport kapasitesi azalan lenfatik sistem ile birlikte lenfatik yük volümü artmıştır $(7,10,12)$.

\section{Epidemiyoloji-Etyoloji}

Lenfödem etyolojiye göre primer lenfödem ve sekonder lenfödem şeklinde sınıflandırılır. Lenfödemin $\% 99$ 'u sekonder lenfödemdir ve tahmini prevelansı 1000 kişide 1 dir. Kadınlarda erkeklerden daha sık görülür (6).

Primer lenfödem, lenfatik sistemin konjenital veya herediter olan gelişim anomalisidir. En sık gelişimsel anomali şekli, hipoplazik tip lenf damarlarıdır. Lenf kollektör sayısı azalmış ve damar çapları küçüktür (5). Primer lenfödem 100000 de 1 oranda görülen nadir bir formdur $(5,13)$. Genellikle alt ekstremiteyi tutar (\%92) (6). Primer lenfödemle ilişkili 7 adet gen bulunmuştur. Sendromik olmayan kalıtımsal bir hastalık olarak veya sendromik hastalığın komponenti olarak karşımıza çıkabilir $(2,5,13)$. Milroy (herediter lenfödem 1A) hastalığı, Meige hastalığı, lenfödem diktiasis sendromu, Hennekam sendromu, Turner sendromu, Noonan sendromu, Emberger's sendromu, Kleinfelter sendromu ve Trizomi 21 primer lenfödemle ilişkili sendromlardan bazılarıdır $(5,13)$. Primer lenfödem, lenfödemin ilk saptandığı yaşa göre 3 e ayrılır $(13,14)$.

- Konjenital Lenfödem: Doğumdan ilk 2 yaşa kadar olan dönem.

- Lenfödem prekoks: En sık pübertede ortaya çıkmakla birlikte 3. dekatta da görülebilir. Primer lenfödemin en sık şeklidir. Çoğunlukla tek taraflı, alt ekstremitede ve kızlarda görülür. En sık puberte ve gebelikte ortaya çıkar.

- Lenfödem tarda: 35 yaş üstü görülür. En nadir formudur.

Sekonder lenfödem ise en sık enfeksiyon, cerrahi ve radyasyon, travma, immobilite, kronik venöz yetmezlik, renal yetmezlikte kullanılan rapamycin tedavisi, obezite, malignite gibi nedenlerden dolayı oluşur. Alt ekstremitede üst ekstremiteden daha cok görülür $(5,6)$. 
- Gelişmekte olan ülkelerde, parazitler (filaryazis) lenfödemin en sık nedenidir $(3,5)$. Dünya genelinde, 73 endemik ülkede, 16,7 milyon vaka bulunmaktadır $(5,15)$. Dünya sağlık örgütünün 2017 verilerine göre 120 milyon kişi enfektedir (16). Filaryazis, enfekte sivrisinekler ile insana bulaşan paraziter bir hastalıktır. En sık wuchereria bancrofti (\%90) ile daha az sıklıkta brugia malayi ve brugia timori parazitleri etkendir $(15,16)$. Larvalar lenfatik sisteme geçerek aylar sonra matür hale gelir ve lenfatik damarlarda hasar oluşturur. Primer tedavi yaklaşımı medikal tedavi ile bulaşma döngüsünü kırmaktır (5). Eğer ulaşılabilirse, komplet dekonjestif terapi, cilt bakımı ve hijyen eğitimi, egzersizler ile etkin bir şekilde tedavi edilebilir (5).

Herpes simplex virüsü, klamidya trakomatis ve tüberküloz nadir görülen diğer enfeksiyöz sekonder lenfödem nedenleridir (6).

- Meme kanseri tedavisi ilişkili lenfödem, gelişmiş ülkelerde sekonder lenfödemin en sık sebebidir. Amerika'da meme kanseri prevelansı yaklaşık 2,4 milyon olmakla birlikte yılda 250,000 meme kanseri vakası saptanmıştır (17). Günümüzde meme kanseri erken tanısı ve tedavisi ile birlikte yaşam süresinin uzaması ile tedavi ilişkili komplikasyonlar hastaların uzun dönem yaşam kalitesini etkilemektedir. Bunlardan birisi de meme kanseri ilişkili lenfödemdir ve cerrahi sonrası ortalama \%21 oranında görülür. Bu oran cerrahinin tipine, radyasyon ve sistemik tedavi alıp almamasına göre ve hastanın spesifik risk faktörlerine göre \%2-\%65 aralığında değişmektedir $(17,18)$. Sırasıyla aksiller lenf nodu diseksiyonu ve sentinal lenf nodu diseksiyonu sonrası lenfödem insidansı $\% 11,8-53,5$ ve $\% 0-15,8$ aralığındadır $(18,19)$. Rejyonel nodal radyoterapi sonrası ise cilt ve cilt altı dokulardaki lenfatik damarlarda ve lenf nodlarında oluşan fibrozis lenfatik akışı etkiler ve \%10-40 oranında lenfödem görülme riski oluşturur $(17,19,20)$. Kemoterapötiklerden taxan grubu ilaçların lenfödemi arttırdığı ile ilgili sınırlı sayıda çalışma mevcuttur. Özellikle docetaxel grubu ilaçların sık rastlanan yan etkilerinden biri olarak extrasellüler sIVı retansiyonu ve ekstremitelerde ödeme neden olduğu biliniyor. Fakat lenfödem riski açısından daha çok çalışmaya ihtiyaç olduğu vurgulanıyor (21-23).

Lenfödem insidansı açısından verilen bu oranlar üst ekstremite için olmakla birlikte gövde ve memede de lenfödem oluşur. Tanı koymak zor olduğundan, rapor edilen gövde ve meme lenfödem insidans oranı \%0-94 aralığında değişmektedir (19).
Meme cerrahisi sonrası lenfödemin ilk 1 yıl içinde görülme olasılığı \%75, ilk 3 yılda \%90 olarak saptanmıştır $(18,23)$. Risk faktörlerinin saptanması, sıklığın arttığı ilk 3 yılda erken tespit açısından önlemlerin alınmasına olanak sağlar.

- Pelvik ve genital kanser cerrahisi sonrası, özellikle inguinal ve pelvik lenf nodu diseksiyonu veya radyoterapi sonrası, lenfödem görülme oranı \%1-47 arası değişmektedir. Jinekolojik kanser ilişkili alt ekstremite lenfödemi, ilk yıl \%75 oranında görülmektedir (24). Malign melanom, serviks, endometrial ve vulvar kanser, prostat ve penil kanser ve yumuşak doku sarkomu cerrahisi ve tedavisi sekonder lenfödem nedenlerinden olan kanser tipleridir (3). Solid organ tümörleri, lenfoma veya yumuşak doku sarkomu gibi malign tümörler ise tedavileri dışında, lenfatik sisteme dışardan bası ile veya lenfatik sistemi infiltre ederek de lenfödeme sebep olabilirler (2).

- Flebolenfödem, batıda en sık sekonder lenfödem nedenlerinden biridir. 50 yaş civarı hastalarda yaklaşık insidansı \%6-7'dir. 70'li yaşlarda \%20'lerin üzerine çıktığı görülmüştür (25). Kronik venöz yetmezlik ile kan kapillerlerinde basınç artar. Tedavi edilmez ise lenfo-venöz yetmezlik oluşur. Post trombotik sendrom, kronik venöz yetmezliğin en sık sebeplerinden biridir. Venöz sistemdeki bu yetmezlik lenfatik sistemde kombine yetmezlik ve lenfödemle sonuçlanır $(5,25)$.

- Artrit, dermatit, sarkoidoz ve dermatozlar gibi inflamatuar hastalıklar, altta yatan mekanizma tam olarak bilinmemekle birlikte lenfödem ile karşımıza çıkabilir.

- Eğer travma öncesi lenfatik sistem sağlam ise travma sonrası lenfödem gelişimi için aşırı skara neden olan şiddetli travma olması gerekir. Ama primer lenfödemi olan hastalarda minör travma da lenfödeme sebep olur.

- İmmobilite

- Endokrin hastalıklar

- İyatrojenik (turnike gibi)

- Obezite, malignensi ilişkili lenfödem hastalarında bağımsız risk faktörü olarak saptanmıştır. Özellikle vücut kitle indeksi (VKI) >30 olanlarda riskin arttığı görülmüştür. Artmış yağ dokusunun lenfatik damarlara bası yaparak lenfödeme neden olduğu düşünülmektedir $(6,26)$. Obezite ilişkili lenfödem olarak tanımlanmaktadır. VKI $>60$ olan hastada ise büyük olasilıkla lenfödem mevcuttur (27).

\section{Lenfödemin klinik değerlendirmesi ve tanı}

Lenfödem tanısı, evrelendirilmesi ve şiddetinin ölçülmesinde henüz altın standart bulunmamaktadır (5). Şu anki tanı ve evreleme kriterleri cilt değişikliklerine ve volüm değişikliklerine bağlıdır. Bu nedenle tam anlamıyla tanı koyma veya erken tanı koyma zorlukları yaşanmaktadır (28). 
Klinik değerlendirme öykü ile başlamalıdır. Hastanın yaşı, mesleği, aile öyküsü, şişlik başlama şekli, kullandığı ilaçlar ve komorbid hastalıklar gibi etyolojiye yönelik ayrıntılı anamnez alınmalıdır. Risk faktörleri değerlendirilmeli ve tedavinin ilk basamağı olan önleyici tedbirler her hastaya göre bireysel belirlenmelidir.

Hastaların genellikle şişlik, sıcaklık hissi, ağırlık hissi, karıncalanma, gerginlik, deri değişiklikleri ve ekstremiteyi"farklı hissetme" şeklinde şikayetleri olur. Ağrı lenfödemde çoğu zaman beklenen bir șikayet değildir $(14,27)$. Hastaların bu şikayetleri erken volüm değişimlerinin birer göstergesidir. Visual analog skalası ile derecelendirme yapılarak bu şikayetler sayısal olarak takip edilebilir $(14,16)$.

Klinik olarak, geçici veya persistan/kronik lenfödem şeklinde tanımlanabilir. Geçici lenfödem, 3 aydan kısa süredir devam eden ve tedavisiz gerileyebilen lenfödem tipidir. Ödem, 3 aydan fazla devam ediyor ise kronik lenfödem olarak tanımlanır (28).

Lenfödemin klinik değerlendirilmesinde öncelikle ekstremite veya gövdenin cilt inspeksiyonu ile rengi, şekli, damar belirginliğinin azalması, lenfatik damarlarda akıntı (lenfore), hiperkeratosis; palpasyon ile gode bırakan ödem varlığı, doku sertliği/fibrozis ve cilt ISISı subjektif olarak değerlendirilir. Stemmer bulgusu, ayakta 2., elde 3. metatarsofalengeal eklem üzerindeki cildin kaldırılması ile cildin yukarı hareket edip etmemesinin gözlenmesidir. Olmaması lenfödemi dışlamaz $(5,27,29)$. Etkilenmiş ekstremitenin el/ayak tutulumu ve parmaklarda " kareleşmişsquared off " görüntüsü lenfödem için tipiktir (4).

Objektif değerlendirme açısından, su yer değiştirme yöntemi altın standart olarak görülse de hem hijyenik hem de kullanım zorlukları nedeni ile kliniklerde kullanılmamaktadır. Çevre ölçümü, belirli noktalardan, belirli aralıklarla ölçüm yapılarak ve iki ekstremite çevre ölçümlerinin farklı olduğu durumlarda kullanılabilir. Kol hacimleri için 4 cm'lik aralıklarla, alt ekstremite için 4-8-12 cm'lik aralıklarla yapılan ölçümlerin kullanılmasının doğru olduğu gösterilmiştir $(5,28,29)$. Çevre ölçümünü kullanmanın, doğruluk açısından bazı kısıt|ılıkları mevcuttur. Sağlıklı kişilerde dominant ve non dominant ekstremite arasında $2 \mathrm{~cm}$ ya da \%8-9 oranında hacim farkı olabilir. Ölçen kişinin bir sonraki ölçümde aynı noktaları kullanması ve mezura sıkma ve çekme farklılıkları, çocukların büyüyor olması gibi bağımlı olduğu durumlar sonucu etkileyebilir $(2,5,27)$. Hacim ölçümü perometre, su yer değiştirme yöntemi ve ekstremitenin çevre ölçüm metodu ile ölçülüp bilgisayar programı aracılığı ile volüm hesaplaması ile bulunabilir. Perometre, kızılötesi teknolojiyi kullanan bir cihazdır. $4 \mathrm{~mm}$ aralıklarla ekstremitede hacimsel ölcüm yapar. Pahalı, taşınabilir olmaması ve el-ayak bölgesini içermemesi kullanımını kısıtlayan etkenlerdir $(2,5)$.

Baş, boyun, gövde, genital organlar ve iki ekstremitenin de tutulduğu veya cilt lezyonları dijital fotograflama ile izlenmelidir $(2,5,28,29)$.

Lenfödem derecelendirme skalası olarak Uluslararası Lenfoloji Derneği (ISL) lenfödem evreleri kullanılır $(2,5,27,29)$.

Evre 0: Latent

çevre ölçümü/volüm: Saptanamaz veya $<1 \mathrm{~cm}$,

pitting: Yok

palpasyon/fibrozis: Değişiklik yok

subjektif yakınma: Yok/var

Evre 1: Hafif

çevre ölçümü/volüm: $<2 \mathrm{~cm}$, elevasyonla azalır.

pitting: Var

palpasyon/fibrozis: Yumuşak/fibrozis yok

subjektif yakınma: Gece azalır

Evre 2: orta

çevre ölçümü/volüm: $>2 \mathrm{~cm}$,

pitting: Yok

palpasyon/fibrozis: Belirgin/orta ya da şiddetli fibrozis

subjektif yakınma: Var, elevasyonla azalmaz

Evre 2-geç evre-: Doku fibrozisinin daha belirgin olduğu bu evrede gode olabilir/olmayabilir.

Evre 3: Şiddetli

çevre ölçümü/volüm: $>5 \mathrm{~cm}$,

pitting: Yok

palpasyon/fibrozis: Sert papillomatöz aşırı büyüme, hiperkeratoz, elefantiazis

subjektif yakınma: Şiddetli rahatsızlık ve immobilite 
Lenfödemin şiddeti ise hafif (hacimin <\%20), orta (\%20 $-40)$, ağır (>\%40) olarak derecelendirilebilir.

Erken ve objektif tanı açısından tonometre, bio-impedans, ultrasonografi (USG), lenfosintigrafi diğer kullanılabilen yöntemlerdir.

Lenfödemin tanı ve şiddetinin değerlendirilmesinde lenfosintigrafi kullanılır. \%96 sensitivite ve \%100 spesifiteye sahiptir. Etyolojiyi tespit etmek, ayırıcı tanıyı yapmak, tedavi sonucunu değerlendirmek için tercih edilir $(2,5,27)$.

Manyetik rezonans (MRI), tomografi (CT), USG lenfödem için spesifik ve sensitif değildir. Cilt kalınlığı ve subkutenöz ödemi gösterebilir (27).

MRI lenfanjiografi sensitivitesi \%68, indocyanin green lenfanjiografi spesifitesi \%55 olarak saptanmış (27).

Lenfanjiodisplazi ve lenfödem sendromlarının saptanması için, MR lenfografi, MR anjiografi, BT lenfogram gibi birçok ileri görüntüleme teknikleri kullanılmaktadır (2).

DXA (dual-energy X-ray absorbsiyometri): Lenfödemli ekstremitenin kimyasal komponentini ortaya koyar. Ekstraselüler sıvı hacmi, yağlı kütle ve yağsız kütleyi belirler. Yapılan çalışmalar tanı öncesi ve tedavi takibinde kullanılabileceğini saptamıştır $(2,5)$.

Bioelektriksel impedans, elektrik akımına karşı direnç ölçülerek ekstraselüler sıvı miktarını belirler. Kemik ve yağ dokusu yalıtkandır, yüksek dirençlidir. Kas ve interstisyel sıvı iletken olduğu için direnci azaltır. Spesifitesi \%80-99, sensifitesi \%30-100 olup özellikle erken dönem lenfödemde tanı koymada yardımcıdır. Lenfödemde, lineerleştirilmiş lenfödem indexi (L-dex) 10 'un üzerindedir (30).

Histopatolojik değerlendirme ise non-spesifik cilt ve yağ dokusu inflamasyonunu gösterir $(27,31)$.

Sıklıkla klinik pratikte ilk kullanılan tekniklerden birisi USG'dir. Non invaziv duplex-doppler derin venöz sistemi ve ekstremite ödemini değerlendirmek için kullanılmaktadır (2).

Lenfödem distikiyazis sendromu ve Milroy hastaları, sırasıyla FOXC2 ve FLT-4 gen analizi ile tanı konulan hastalıklardan ikisidir.

\section{Lenfödem tedavisi}

Lenfödem tedavisinin ilk basamağı ekstremiteyi normal ya da normale yakın boyuta ulaştırmak ve komplikasyonları önlemektir, çünkü tedavide kür yoktur $(11,19)$.

Komplet dekonjestif terapi (KDT), lenfödem ve ilişkili durumlarda kullanılan 4 bileşenli bir tedavidir $(1,11,19)$.

- Manuel lenf drenajı (MLD)

- Kompresyon tedavisi

- Remedeal egzersizler

- Cilt bakımı

Lenfödem tedavisi iki fazlı yapılmaktadır.

Faz 1: Yoğun veya dekonjestif tedavidir. Hasta her gün tedaviye gelir. Süresi hastaya göre değişmekle birlikte üst ekstremite için ortalama üç hafta, alt ekstremite için dört haftadır.

Faz 2: Hastanın, Faz 1 deki kazanımlarını sürdürebilmesini hedefler. Bası giysileri gün boyu giyilmeli ve gece bandajı yapılmalıdır. Bu dönem ömür boyu devam eder.

Cilt Bakımı (1,11,32): Bütün lenfödem hastaları titiz cilt ve tırnak bakımı konusunda eğitilmelidir. Cilt bakımının genel prensibinin amacı, cilt bütünlüğünü korumaktır. Yapılan çalışmalarda, özellikle filariazis ilişkili lenfödemde öz bakımın tek başına hastalığın ilerlemesini durdurduğu saptanmıştır (15).

- Cilt, doğal ve nötral ph lı sabunlarla günlük olarak yıkanmalı, yumuşak havlu ile travma yaratmadan kurulanmalı, sonrasında su bazlı nemlendirici ile nemlendirilmelidir. Mineral, vazelin ve yağ içerikli ürünler tercih edilmemelidir.

- Hastalar etkilenmiş olan ekstremiteyi düzenli olarak gözlemlemeli kızarıklık, hassasiyet, ısı artışı var ise doktoruna başvurmalıdır.

- Travmalardan, sinek ısırığından, evcil hayvan yaralanmarından kendini korumalıdır.

- Güneşle direkt temastan kaçınmalı gerekirse güneş koruyucu kullanmalıdır.

- Yemek pişirken ve bahçe işleri yaparken eldiven takmalıdır.

- Çok ağır obje taşımamalıdır.

- Etkilenen koldan enjeksiyon yapılmamalı, tansiyon ölçülmemelidir.

- Farkındalık için lenfödem bilekliği kullanılabilir. 
Egzersiz $(1,11)$ : Egzersiz olmadan başarılı bir lenfödem tedavisi düşünülemez. Kanser ilişkili lenfödemde öz bakım rutini ile birlikte progresif dirençli egzersizlerin hastalığın ilerlemesini durdurduğu ve hacminin küçülmesini sağladığı görülmüştür (15).

Egzersizler bası giysisi veya bandaj ile yapılmalıdır. Aşırı yüklenme, ağrı ve rahatsızlık veren egzersizler yapılmamalıdır.

Egzersiz, kas güçlenmesini, kardiyovasküler fonksiyonu, psikolojik iyilik halini ve fonksiyonel kapasiteyi arttırır. Egzersiz reçetesi mutlaka bireysel olarak hazırlanmalıdır.

Yoğun fazda uygulanan egzersizlere "remedeal egzersizler" yani tedavi edici egzersizler denir. Aktif, tekrarlı, dirençli olmayan egzersizleri içerir.

Aerobik egzersizler, abdominal basıncı arttırarak duktus torasikus pompasını aktivite eder. Yürüme, yüzme, bisiklet sürme önerilen aerobik egzersizlerdir.

Hafif dirençli egzersizler kas pompalarınn aktivasyonunu ve lenfatik akımı arttırır. Kuvvetlendirme egzersizleri uygun yoğunlukta yapılmaz ise yaralanmalara ve lenfödemin artmasına sebep olabilir. Hastanın son 3 aydır enfeksiyon geçirmemiş olması, drenaj uygulanmış ve gerekli bası giysisi ve bandaj kullanıyor olması gerekmektedir.

Yoga, lebed yöntemi, tai-chi, pilates gibi hastanın genel sağlık durumunu merkeze alan özel egzersiz çeşitleri de önerilmektedir $(11,33)$.

Su içi egzersizler, ortalama $32^{\circ} \mathrm{C}$ suyun hidrostatik basıncı ve masaj etkisi ile lenfatik akımı arttırabilir. Lenfödem tedavisinin idame fazında uygun bir egzersiz alternatifidir (2).

Elevasyon: Etkilenmiş ekstremitenin, kalp seviyesinde eleve etmenin venöz drenajı arttırarak, kapiller basınc ve lenf üretimini azaltarak etkileyeceği düşünülmektedir $(2,32)$.

Solunum egzersizleri: Solunum sırasında, diaframın yukarı ve aşağı hareketi lenf sıvısının dolaşıma dönmesini arttırır.

\section{Manuel Lenf Drenajı}

MLD, terapistin, eliyle yaptığı değişen derecelerde basınç ile gerçekleşen yüzeyel doku germe tekniğidir. Vodder, Földi, Leduc veya Casley-Smith gibi değişik MLD yöntemleri vardır (34). Klasik masaj veya öflerajdan farklı bir tekniktir. Bu masaj teknikleri lenfatik damarları yaralayabilmektedir (2).

MLD, sabit daireler, pompa, çark, kepçeden oluşan 4 temel Vodder vuruşu içerir. Bu vuruşların çalışma ve dinlenme fazları vardır. Her bir çalışma fazı 1 saniye sürmeli, aynı bölgeye 5-7 kez tekrarlanmalıdır. Çalışma fazında, lenf kapillerlerindeki ankoring filamanlarının gerilmesi ve lenfanjiomotorisitenin artması sağlanır. Uygulanan basınç yüksek olmamalıdır $(1,2,11)$. Temel vuruşlara ek olarak, derin abdominal teknik, ödem tekniği, fibrozis tekniği, vaza vazorum tekniği gibi ek teknikler vardır. Teknik olarak, proksimalden distale doğru, sırasıyla nonödematöz gövde yarımı, ödematöz gövde yarımı ve ödemli ekstremitenin proksimali ve son olarak distali şeklinde sıralama şeklinde özetlenebilir (34). MLD'nin kondrendike/relatif kondrendike olduğu durumlar; kardiak ödem, böbrek yetmezliği, akut enfeksiyonlar, akut bronşit, akut derin ven trombozu, maligniteler, bronşial astım, hipertansiyon sayılabilir.

\section{Kompresyon tedavisi}

Kompresyonda amaç, MLD ile uzaklaşmış sıvının tekrar birikmesini önlemek. Kondrendikasyonları/relatif kondrendikasyonlar; kardiak ödem, akut enfeksiyonlar, hipertansiyon, kardiak aritmi, ekstremitede azalmış veya kaybolmuş duyu, kısmi veya tam paralizi, flask ekstremite, ileri yaş, konjestif kalp yetmezliği, hafif-orta dereceli periferik tıkayıcı arter hastalıkları, diyabet, malign lenfödemdir.

\section{Bandajlama}

MLD ve nemlendirici uygulamasını takiben teri emen ve cildi pedleme malzemelerinden koruyan pamuklu bir çorap giydirilir. Sonrasında ekstremiteye, kısa gerim bandajı farklı genişlikte ve tabaklar şeklinde uygulanır. Bandajlama, KDT'nin olmazsa olmaz komponentidir. Yirmi üç saat yani bir sonraki MLD ye kadar bu şekilde kalmalıdır. Hasta bandajlar sarılı şekilde günlük yaşam aktivitelerine devam etmeli ve dekonjestif egzersiz programını uygulamalıdır $(1,34)$.

\section{Bası giysisi}

Ödemli ekstremitenin dekonjesyonu sırasında ulaşılan tedavi başarısını korumak için bası giysilerini hastanın hayat boyu giymesi gereklidir. Tedavisi yapılmamış ödemli ekstremitede kullanılmamalıdır. Tek başına ödemi azaltmada faydası yoktur (1). Uygun giysiyi seçmek çok önemlidir. Hastaya uygun kompresyon basıncı, hastanın basınca duyarlılığı, hasta için giysiyi giymek/çıkarmanın zorluğu bası giysisinin etkinliği için önemli noktalardır (1). 


\section{Fizik tedavi modaliteleri}

Elektrik stimülasyonu

Elektrik akımları, kas kasılmasını arttırmak, kan akımını arttırmak, ağrıyı azaltmak, ödem azaltmak ve doku iyileşmesini hızlandırmak amaçlarıyla kullanılmaktadır $(1,35)$.

\section{Termal terapi}

Yapılan çalışmalarda, bandaj altında derinin yavaşca ısındığı ve düşük derecede ısının iyileşmeyi arttırabildiği görülmüştür. Temel tedavi programında sıcak, soğuk paketler, saunalar, kontrast banyo ve parafin gibi uygulamalar kondrendikedir $(11,14)$.

\section{Düşük dereceli lazer terapisi}

Doku sıcaklığını değiştirmeden, derin dokuya ulaşarak sert dokuyu yumuşattığı ve ağrıyı azalttığı düşünülüyor $(2,11,14)$.

\section{Ardışık intermittan pnömotik kompresyon}

Pnömotik kompresyon kullanımı halen tartışmalı bir konudur. Pompalar, interstisyel aralıktan sadece suyu çıkarabilir, protein gibi büyük molekülleri çıkaramaz. Bu nedenle başlangıçta ekstremite küçülür. Kompresyon tedavisi uygulanmaz ise lenfödem şiddetlenir. Bu nedenle, vücut kadranları ve drenaj bölgeleri hazırlanmadan kullanılmamalıdır. Gövde ve ekstremite giysilerini içeren ve çok bölmeli ardışık kompresyon cihazlarının, özellikle KDT'nin 2. fazında kullanılması önerilmektedir $(2,11,14)$.

\section{Ekstrakorporeal veya radyal şok dalga tedavisi, tera-} pötik ultrason, akua lenfatik tedavi, hiperbarik oksijen tedavisi gibi birçok fizik tedavi ajanları araştırılmaya açık ve etkinliği hakkında daha güçlü kanıtlar sağlanması gereken tedavi metodlarıdır (1).

\section{Medikal ajanlar}

Bitkisel tedaviler, inflamatuar aktiviteyi inhibe ederek, kapiller geçirgenliği azaltarak ve venöz dönüşü arttırarak

\section{Kaynaklar}

1. Zuther JE. Complete decongestive therapy. In: Zuther JE, Norton S, editors. Lymphedema Management: The Comprehensive Guide for Practitioners, 3rd ed. New York: Thieme; 2013. pp.128-63.

2. Executive Committee. The diagnosis and treatment of peripheral lymphedema: 2016 consensus document of the International Society of Lymphology. Lymphology 2016;49:170-84.

3. Rockson SG, Rivera KK. Estimating the population burden of lymphedema. Ann NY Acad Sci 2008;1131:147-54. [CrossRef]

4. Waschke J, Böckers T, Paulsen F. Sobotta: Anatomi Konu Kitabı. Çeviri Editörü : Sargon MF. Ankara: Güneş Tıp Kitapevleri; 2016. pp.38-44. fayda sağlayabilir. Benzopironlar, bitki özleri ve saponinler olarak 3 e ayrılabilirler. Kumarin en iyi bilinen alfa bezopriondur. Gama benzopironlar, flavonoidler ve flavonlar olarak 2 ye ayrılır. En iyi bilinen saponinler ise meyan kökü ve at kestanesidir. Fakat bitkisel ürünlerin kullanımı ile ilgili yeterli kanıt bulunmadığı için hastaya zarar vermeyecek şekilde geleneksel tamamlayıcı tedavi yöntemi olarak önerilebilir (36).

\section{Cerrahi}

Lenfödem tedavisi uygulamaları konservatif, farmakolojik, cerrahi ve alternatif olarak 4 gruba ayrılabilir. Cerrahiye aday olan hastalar belirlenirken etkin KDT ye rağmen 12 ay içinde lenfödemin progrese olması, evrenin artması, lenfosintigrafide dermal geri akım, bir yılda en az iki kez tedavide başarısızlık gibi kriterlere göre karar veriliyor. Özellikle cerrahiyi kabul eden hastaların ömür boyu KDT tedavisine devam edeceklerini bilmeleri gerektiği vurgulanıyor. Cerrahi tedavi, ablatif ve rekonstrüktif fizyolojik operasyonlar şeklinde ana başlıklara ayrılabilir. Ablatif tedaviler, elefantiasis gibi ileri lenfödemde ve fizyolojik rekonstrüktif işlemlere cevap alınamadığında uygulanmaktadır. Fizyolojik metodlarda, lenfatik damarların rekonstrüksiyonu ile alternatif yolların yeniden oluşturulması hedeflenir. Iki metod vardır. Lenfatikovenöz anastomoz ve vaskülarize lenf nodu transferidir $(37,38)$.

\section{Sonuç}

Lenfödem tedavisinde, erken tanı ve tedavi çok önemlidir. Hasta ve yakınlarının bilgilendirilmesi tedavinin en önemli basamaklarından biridir ve hastanın tedaviye uyumunu arttırır. Lenfödem tedavisi, interdisipliner bir ekip işidir; ekibin lideri fiziyatristtir. Ekibin diğer üyeleri öncelikle hasta ve ailesi, lenfödem rehabilitasyonu eğitimi almış terapist, gerekli durumlarda diğer branşlardan uzman hekimlerdir.
5. Zuther JE. Pathology. In: Zuther JE, Norton S, editors. Lymphedema Management: The Comprehensive Guide for Practitioners, 3rd ed. New York: Thieme; 2013. pp.46-122.

6. Grada AA, Phillips TJ. Lymphedema: Pathophysiology and clinical manifestations. J Am Acad Dermatol 2017;77:1009-20. [CrossRef]

7. Sindel $D$, Şen E. Lenfatik sistem fizyolojisi ve lenfödem patofizyolojisi. İçinde: Alper S, Akalın E, Gündüz B, editörler. Lenfödem Tanı ve Tedavi: Lenfatik sistem anatomisi. İzmir: O’Tıp kitapevi 2017. ss.13-8.

8. Alper S, Akalın E, Gündüz B. Lenfödem Tanı ve Tedavi: Lenfatik sistem anatomisi. İzmir: O’Tıp kitapevi, 2017:1-11. 
9. Zuther JE. Anatomy. In: Zuther JE, Norton S, editors. Lymphedema Management: The Comprehensive Guide for Practitioners, 3rd ed. New York: Thieme; 2013. pp.2-27.

10. Suami H, Scaglioni MF. Anatomy of the Lymphatic System and the Lymphosome Concept with Reference to Lymphedema. Semin Plast Surg 2018;32:5-11. [CrossRef]

11. Guyton AC, Hall JE. Guyton ve Hall Tıbbi Fizyoloji: Güneş Tıp Kitabevleri, 2017.

12. Zuther JE. Physiology. In: Zuther JE, Norton S, editors. Lymphedema Management: The Comprehensive Guide for Practitioners, 3rd ed. New York: Thieme; 2013. pp.29-43.

13. Quéré I, Moffatt C. Care of children with lymphoedema: International lymphoedema framework; 2010. https://www.lympho.org/ portfolio/care-of-children-with-lymphoedema/

14. Rockson SG. Lymphedema. Am J Med 2001;110:288-95. [CrossRef]

15. Douglass J, Graves P, Gordon S. Self-Care for Management of Secondary Lymphedema: A Systematic Review. PLoS Negl Trop Dis 2016;10:e0004740. 10.1371/journal.pntd.000474

16. World Health Organization. Lymphatic filariasis: Epidemiology. http://www.who.int/lymphatic_filariasis/epidemiology/en/

17. Smile TD, Tendulkar R, Schwarz G, Arthur D, Grobmyer S, Valente S, et al. A review of treatment for breast cancer-related lymphedema. Am J Clin Oncol 2018;41:178-90. [CrossRef]

18. Nguyen TT, Hoskin TL, Habermann EB, Cheville AL, Boughey JC. Breast cancer-related lymphedema risk is related to multidisciplinary treatment and not surgery alone: results from a large cohort study. Annals of Surgical Oncology 2017;24:2972-80. [CrossRef]

19. Gebruers N, Verbelen H, De Vrieze T, Vos L, Devoogdt N, Fias L, Tjalma W. Current and future perspectives on the evaluation, prevention and conservative management of breast cancer related lymphoedema: A best practice guideline. Eur J Obstet Gynecol Reprod Biol 2017;216:245-53. [CrossRef]

20. Shaitelman SF, Chiang Y-J, Griffin KD, DeSnyder SM, Smith BD, Schaverien MV, et al. Radiation therapy targets and the risk of breast cancer-related lymphedema: a systematic review and network meta-analysis. Breast Cancer Res Treat 2017;162:201-15. [CrossRef]

21. Kilbreath SL, Refshauge KM, Beith JM, Ward LC, Ung OA, Dylke ES, et al. Risk factors for lymphoedema in women with breast cancer: A large prospective cohort. Breast (Edinburgh, Scotland) 2016;28:2936. [CrossRef]

22. Zhu W, Li D, Li X, Ren J, Chen W, Gu H, et al. Association between adjuvant docetaxel-based chemotherapy and breast cancer-related lymphedema. Anti-Cancer Drugs 2017;28:350-5. [CrossRef]

23. Swaroop MN, Ferguson CM, Horick NK, Skolny MN, Miller CL, Jammallo LS, et al. Impact of adjuvant taxane-based chemotherapy on development of breast cancer-related lymphedema: results from a large prospective cohort. Breast Cancer Res Treat 2015;151:393403. [CrossRef]
24. Hareyama H, Hada K, Goto K, Watanabe S, Hakoyama M, Oku K, et al. Prevalence, classification, and risk factors for postoperative lower extremity lymphedema in women with gynecologic malignancies: a retrospective study. Int J Gynecol Cancer 2015;25:751-7. [CrossRef]

25. Farrow W. Phlebolymphedema - a common underdiagnosed and undertreated problem in the wound care clinic. J Am Col Certif Wound Spec 2010;2:14-23. [CrossRef]

26. Jung SY, Shin KH, Kim M, Chung SH, Lee S, Kang HS, et al. Treatment factors affecting breast cancer-related lymphedema after systemic chemotherapy and radiotherapy in stage II/III breast cancer patients. Breast Cancer Res Treat 2014;148:91-8. [CrossRef]

27. Greene AK, Goss JA. Diagnosis and Staging of Lymphedema. Semin Plast Surg 2018;32:12-6. [CrossRef]

28. Johnson KC, Kennedy AG, Henry SM. Clinical measurements of lymphedema. Lymphat Res Biol 2014;12:216-21. [CrossRef]

29. Delialioğlu S. Lenfödemde klinik değerlendirme. İçinde: Alper $S$, Akalın E, Gündüz B, editörler. Lenfödem Tanı ve Tedavi: Lenfatik sistem anatomisi. İzmir: O'Tıp kitapevi 2017.

30. Qin ES, Bowen MJ, Chen WF. Diagnostic accuracy of bioimpedance spectroscopy in patients with lymphedema: A retrospective cohort analysis. J Plast Reconstr Aesthet Surg 2018;71:1041-50. [CrossRef]

31. Whitworth PW, Cooper A. Reducing chronic breast cancer-related lymphedema utilizing a program of prospective surveillance with bioimpedance spectroscopy. Breast J 2018;24:62-5. [CrossRef]

32. International Lymphoedema Framework. Best Practice for the Management of Lymphoedema 2006. Available from: https://www.lympho.org/portfolio/ best-practice-for-the-management-of-lymphoedema/

33. Sandel SL, Judge JO, Landry N, Faria L, Ouellette R, Majczak M. Dance and movement program improves quality-of-life measures in breast cancer survivors. Cancer Nurs 2005;28:301-9. [CrossRef]

34. Schaverien MV, Moeller JA, Cleveland SD. Nonoperative Treatment of Lymphedema. Semin Plast Surg 2018;32:17-21. [CrossRef]

35. Grushina TI. What physiotherapeutic method for the treatment of post-mastectomy lymphedema is the most effective? Vopr Kurortol Fizioter Lech Fiz Kult 2017;94:59-66. [CrossRef]

36. Poage EG, Rodrick JR, Wanchai A, Stewart BR, Cormier JN, Armer JM. Exploring the usefulness of botanicals as an adjunctive treatment for lymphedema: a systematic search and review. PM R 2015;7:296310. 10.1016/j.pmrj.2014.09.01

37. Gallagher K, Marulanda K, Gray S. Surgical Intervention for Lymphedema. Surg Oncol Clin North Am 2018;27:195-215. [CrossRef]

38. Soran A, Kamalı Polat A. Lenfödemde cerrahi tedavi. İçinde: Alper S, Akalın E, Gündüz B, editörler. Lenfödem Tanı ve Tedavi: Lenfatik sistem anatomisi. İzmir: O'Tıp kitapevi 2017. ss.155-63. 